\title{
CHARAKTERYSTYKA ORAZ ROZWIĄZANIA TECHNOLOGICZNE SKRZYDŁA SAMOLOTU F-16 BLOCK 52+
}

\author{
Andrzej Żyluk, MirosŁaw Adamski, Konrad Zwoliński, Tomasz Grzybowski \\ Lotnicza Akademia Wojskowa, Wydzial Lotnictwa, Dęblin \\ e-mail: a.zyluk@law.mil.pl; m.adamski@law.mil.pl; k.zwolinski@ron.mil.pl; t.grzybowski@ron.mil.pl
}

\begin{abstract}
Celem artykułu jest identyfikacja istniejącego, dostępnego w literaturze modelu dynamiki lotu samolotu F-16. Identyfikacja ta oznacza pełne zrozumienie tego modelu, zastosowanych w nim uproszczeń, nałożonych na model ograniczeń oraz określenie charakterystyk aerodynamicznych samolotu. Przedstawiono rozwiązania technologiczne majace na celu uzyskanie maksymalnie wysokiej manewrowości przy jednocześnie niewielkiej masie oraz niskim koszcie jednostkowym produkcji tego samolotu.
\end{abstract}

Stowa kluczowe: F-16, mechanizacja, aerodynamika, klapy

\section{Wstęp}

Lockheed Martin F-16 jest jednosilnikowym lekkim samolotem wielozadaniowym. Zbudowany został w układzie klasycznego średniopłata z pojedynczym statecznikiem pionowym, o konstrukcji mieszanej z przewagą stopów aluminium.

Skonstruowanie samolotu, który osiągałby prędkości naddźwiękowe i jednocześnie był wysoce manewrowy zarówno w locie z prędkościami poddźwiękowymi, jak i naddźwiękowymi, wymagało rozwiązania wielu problemów. W celu uzyskania wymaganych osiągów nie wystarczyło po prostu zwiększać ciągu zespołu napędowego czy powiększać zbiorników paliwa. Harry Hillaker, uważany za jednego z „ojców” myśliwca F-16, zdawał sobie sprawę, że układ aerodynamiczny nowego myśliwca musi być oparty o nowatorskie, niestandardowe rozwiązania, by mógł on wypełniać wspomniane trudne wymagania taktyczno-techniczne. Główną uwage przywiązano do jak najmniejszego współczynnika oporu powietrza, jak największej doskonałości aerodynamicznej w szerokim zakresie prędkości i kątów natarcia, a także niewielkiego zużycia paliwa. Harry Hillaker, pracujący jako konstruktor lotniczy w General Dynamics, stwierdził, że najtrudniejszym zadaniem było znalezienie właściwych proporcji pomiędzy sprzecznymi wymaganiami dużej manewrowości i odpowiedniego zasięgu. Zwiększenie manewrowości w płaszczyźnie poziomej uzyskuje się m.in. przez powiększenie powierzchni nośnej, co nieuchronnie prowadzi do wzrostu wielkości i masy samolotu. Zastosowanie metody elementów skończonych i zaawansowanych technologii przy opracowaniu przejścia skrzydło-kadłub pozwoliło na uzyskanie płatowca lżejszego o około $590 \mathrm{~kg}$ niż opracowanego przy użyciu klasycznych technik projektowych. Aby uwypuklić ten fakt przedstawicielom Pentagonu, inżynierowie GD obliczyli, że cena jednostkowa płatowca wyniesie około 132 USD $/ \mathrm{kg}$, co pozwoli zaoszczędzić około 80 tys. USD. Bezpośredni związek z manewrowością pionową ma stosunek ciągu zespołu napędowego do masy samolotu. Aby go poprawić, można zmniejszyć masę statku powietrznego albo zwiększyć ciąg silnika. Łatwiejsze jest to drugie rozwiązanie, lecz prowadzi ono do wzrostu zużycia paliwa, a w konsekwencji do ograniczenia zasięgu. Dlatego dwa czynniki: ciąg silnika i ilość paliwa w zbiornikach stały się punktem wyjścia prac. Kolejnym problemem był wybór układu jedno- lub dwusilnikowego.

Wzrost niezawodności konstrukcji lotniczych spowodował, że ówczesne prognozy na rok 1980 mówiły o 5,3 wypadkach na 100 tys. godzin lotu samolotu jednosilnikowego i 5,0 dwusilnikowego. 
Ponadto uznano, że prawdopodobieństwo awarii jednego silnika na samolocie dwusilnikowym jest dwukrotnie wyższe niż na jednosilnikowym, a taka awaria zmusza i tak do przerwania zadania. Ostatecznie zdecydowano zastosować niemodny wówczas układ jednosilnikowy, gdyż daje on $15 \%$ zysku na masie konstrukcji.

Po raz pierwszy w konstrukcji amerykańskiego samolotu myśliwskiego zrezygnowano z wymagania uzyskiwania dużych prędkości. Uznano, że z samolotami MiG-25 będzie prowadził walkę F-15, natomiast LWF miał działać w strefie przyfrontowej, gdzie operujące samoloty nie będą musiały rozwijać prędkości przekraczających $\mathrm{Ma}=1,6$. Wówczas główną rolę odgrywać miała manewrowość samolotu na typowych prędkościach walk powietrznych, odpowiadających liczbie $\mathrm{Ma}=0,6, \ldots, 1,2$, a z uwzględnieniem fazy pościgu do Ma $=1,6$. Liczyła się przy tym nie tylko zdolność do wykonywania ciasnych zakrętów w płaszczyźnie poziomej, ale także nadmiar ciągu, umożliwiający wykonywanie figur pionowych bez utraty prędkości, co skutkowało wywalczeniem lepszej pozycji do ataku na przeciwnika.

Aby samolot przeciwnika nie mógł swobodnie wyjść z nawiązanej walki, założono uzyskiwanie dobrych przyśpieszeń $\mathrm{w}$ zakresie $\mathrm{Ma}=0,6, \ldots, 1,6$. W praktyce oznaczało to zbudowanie samolotu zdolnego do rozwijania prędkości w granicach $\mathrm{Ma}=1,8, \ldots, 2,0$ na średnich wysokościach. Wymagania mówiły o uzyskaniu maksymalnych własności manewrowych w przedziale $\mathrm{Ma}=0,6, \ldots, 1,6$ zoptymalizowanych do wysokości 10-13 tys. metrów, a także aby masa bojowa z 2/3 zapasu paliwa i uzbrojeniem do prowadzenia walk powietrznych nie przekroczyła 20 tys. funtów, czyli $9070 \mathrm{~kg}[5]$.

\section{Wybór skrzydła F-16 [2]-[4]}

Po zaprojektowaniu kadłuba i wyborze zespołu napędowego, inżynierowie przystąpili do konstrukcji płata. W czasie opracowywania samolotu zbadano cztery różne układy skrzydeł: proste (trapezowe), skośne, o zmiennej geometrii oraz delta. Skrzydło skośne miało najgorsze właściwości i zostało szybko odrzucone. Początkowo najbardziej korzystne wydawało się być skrzydło typu „delta”, którego zaletą była zdolność do wykonywania stosunkowo ciasnych zakrętów i dobre charakterystyki w locie poziomym, ale zarazem istotną wadą - tendencją do gwałtownej utraty prędkości w nich. Przez pewien czas rozważano zastosowanie układu ze zmienną geometrią płata, co teoretycznie najlepiej korespondowało ze sprzecznymi wymaganiami zwrotności i uzyskania dobrych przyspieszeń, przy uzyskiwaniu jak najlepszego zasięgu. Jednak przyrost masy konstrukcji w połączeniu ze zmniejszoną wytrzymałością takiego skrzydła na duże przeciążenia stały się przyczyną odrzucenia tego układu. Ostatecznie więc wybrano skrzydło trapezowe o średnim skosie krawędzi natarcia i o prostej krawędzi spływu. Był to układ pośredni pomiędzy skrzydłem trójkątnym a skośnym, umożliwiający zbalansowanie wad i zalet obu tych płatów. Układ taki oferował najlepszą kombinację dobrej manewrowości, dużego przyspieszenia i doskonałej charakterystyki siły nośnej, co zapewniało dobre charakterystyki wysokościowe.

Przy określonym ciągu zespołu napędowego prędkości naddźwiękowe uwarunkowane są oporem aerodynamicznym samolotu, który zależy głównie od parametrów geometrycznych skrzydeł, takich jak: względna grubość profilu $g$, kąt skosu krawędzi natarcia (leading edge sweep) $\chi$ i wydłużenie skrzydeł (aspect ratio) $\lambda$. Im cieńsze są profile skrzydeł, im większy jest kąt skosu i mniejsze wydłużenie, tym większa jest liczba Ma $k_{r}$ skrzydeł, mniejszy przyrost oporu falowego podczas przekraczania bariery dźwięku $(\mathrm{Ma} \approx 1)$ i mniejszy opór aerodynamiczny przy prędkościach naddźwiękowych (rys. 1 i 2) [3].

Jednak konsekwencją małej względnej grubości, dużego skosu i małego wydłużenia skrzydeł jest ich niewielka nośność. Charakterystyczną cechą skrzydeł skośnych o małym wydłużeniu jest zwiększone pochylenie krzywej $c_{z}=f(\alpha)$ w stosunku do pochylenia krzywej skrzydeł prostych, co powoduje, że krytyczny kąt natarcia tych skrzydeł ma znaczną wartość (rys. 2 i 3 ). 

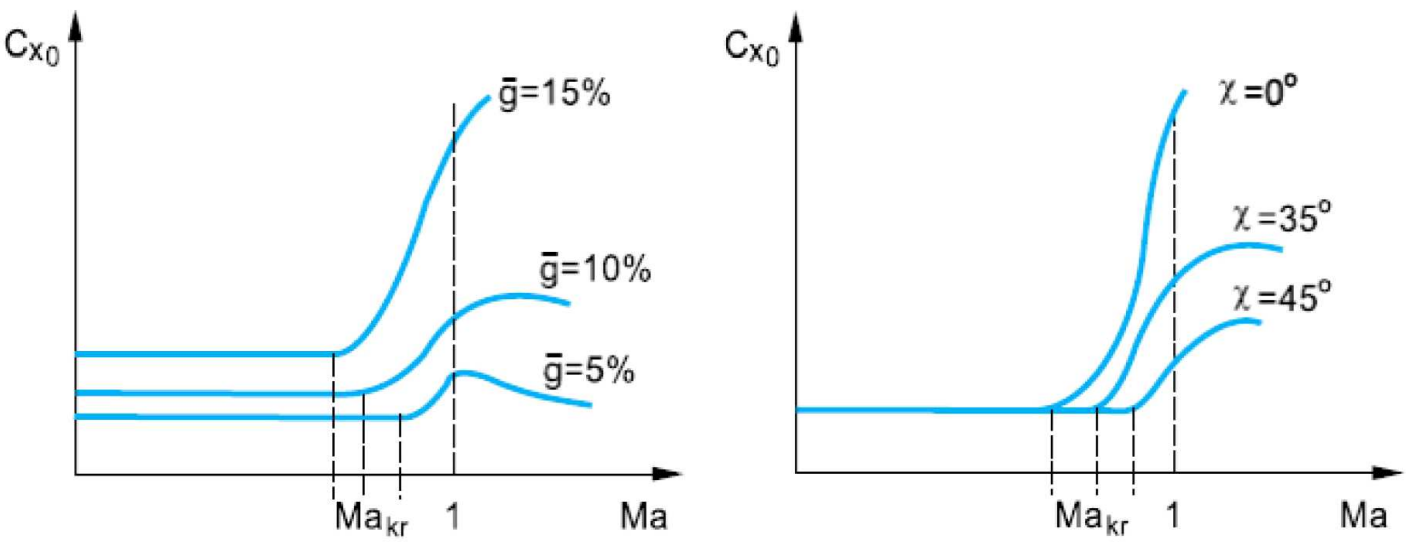

Rys. 1. Wpływ względnej grubości i kąta skosu skrzydeł na współczynnik oporu aerodynamicznego
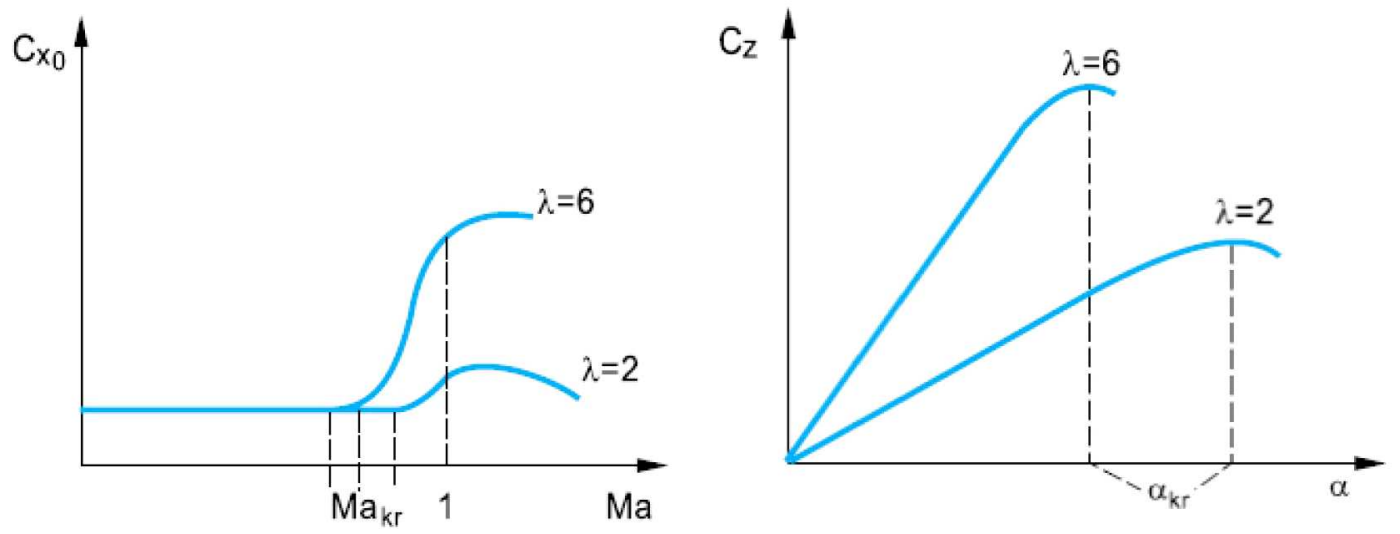

Rys. 2. Wpływ wydłużenia skrzydeł na współczynnik oporu aerodynamicznego i współczynnik siły nośnej
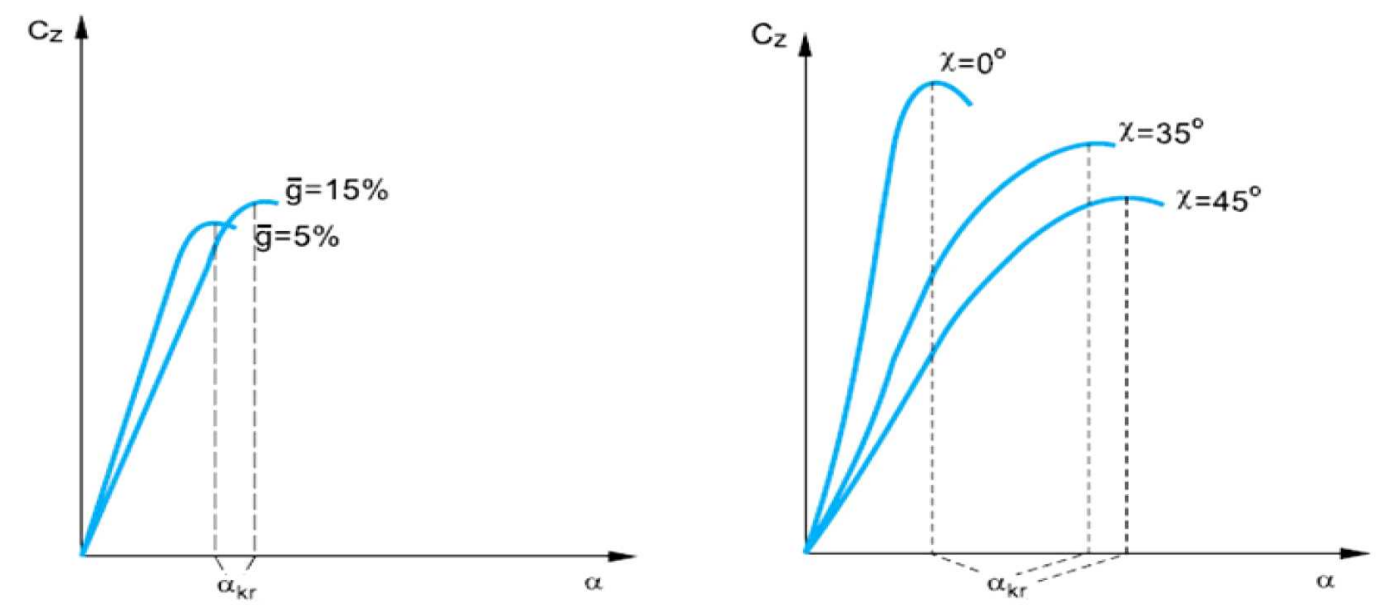

Rys. 3. Wpływ względnej grubości i kąta skosu skrzydeł na charakterystykę $c_{z}=f(\alpha)$

\section{Co z mechanizacją skrzydła F-16? [3]}

W celu uzyskania dużej manewrowości samolotu przy zastosowaniu parametrów skrzydeł samolotu naddźwiękowego podjęto działania mające znacznie zwiększyć nośność płata. Zwiększenie siły nośnej uzyskano dzięki zastosowaniu laminarnych skrzydeł pasmowych (LEX - leading edge extension) i klap krawędzi natarcia (LEF - leading edge flaps). Głównym elementem skrzydła 
pasmowego jest moduł przykadłubowy, o bardzo małym wydłużeniu, który przechodząc płynnie w kadłub, tworzy element nośny zwany napływem (rys. 4). Jego głównym przeznaczeniem jest generowanie wiru aerodynamicznego, którego intensywność rośnie w miarę zwiększania kąta natarcia i poszerzenie możliwości manewrowania w locie na tych kątach. Wytworzony wir, zwiększając energię przepływu strugi na części zewnętrznej płata, powoduje opóźnienie oderwania strugi na nasadzie skrzydła i zapewnia stateczność kierunkową. Jednak ważne jest, aby wytworzone wiry nie ,zaplatały się" i nie powodowały szkodliwej, gwałtownie zwiększającej opór turbulencji, co uzależnione jest od odpowiedniego doboru obrysu płata. Skrzydło pasmowe umożliwiło zwiększenie dopuszczalnych przeciążeń konstrukcji do $n_{z}=9$. Wewnętrzna część płata, tworząc z kadłubem integralną całość i uczestnicząc w wytwarzaniu siły nośnej, przyczyniła się do wzrostu sztywności i wytrzymałości konstrukcji. Ponadto niewielka stosunkowo masa samolotu spowodowała obniżenie sił działających na płatowiec przy dużych przeciążeniach (przy przeciążeniu $n_{z}=9$ ). Konstrukcja o większej masie musi wytworzyć proporcjonalnie większą siłę nośną, która zrównoważy ciężar tego samolotu.

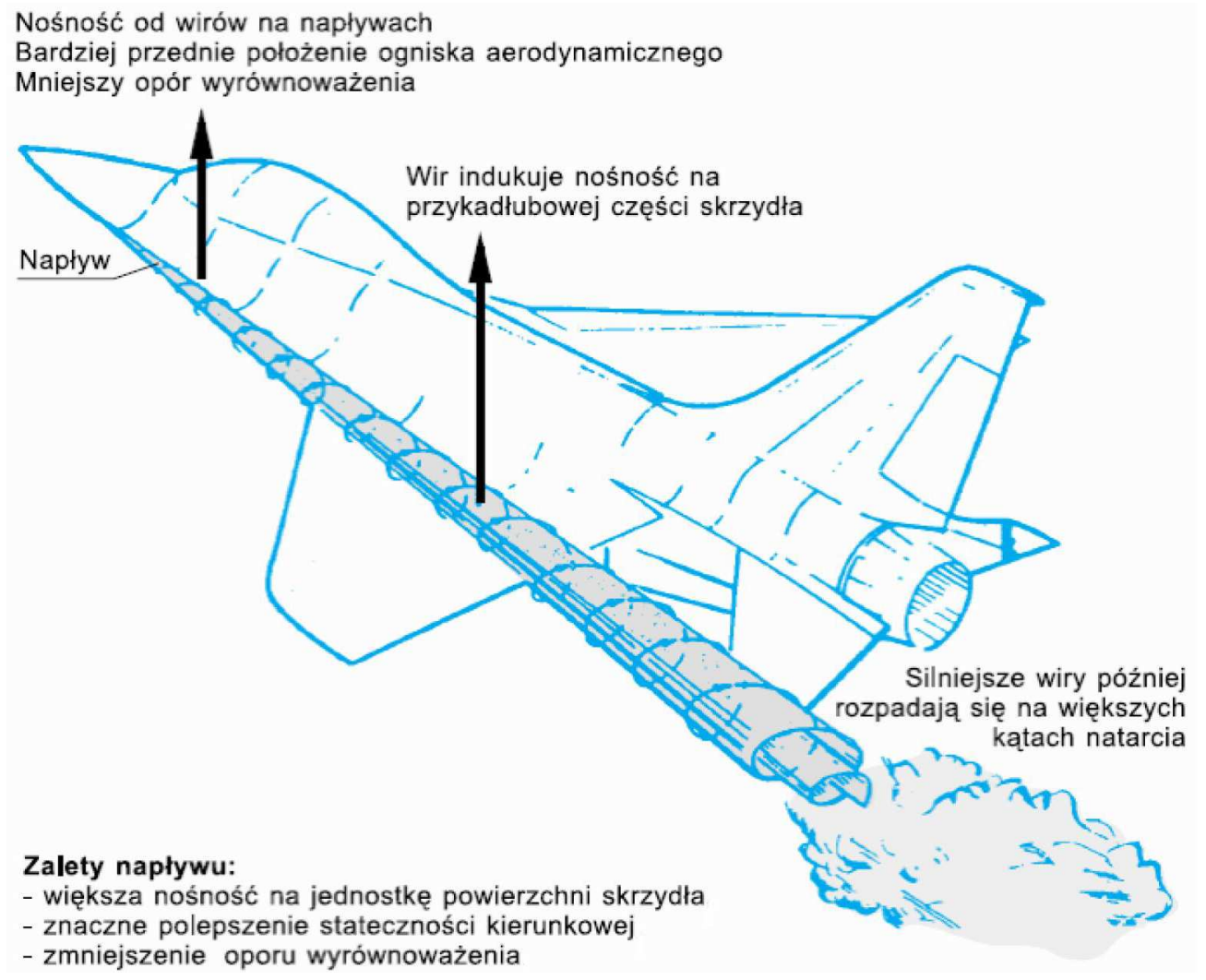

Rys. 4. Działanie napływu skrzydła pasmowego

Dodatkowe zastosowanie klap krawędzi natarcia, wyginających szkieletową profili skrzydeł, wpływa na zwiększenie nośności również tych części skrzydeł, które nie są objęte wirami [2] (rys. 5). Jak widać, współczynnik siły nośnej skrzydeł pasmowych z klapami krawędzi natarcia jest większy od $c_{z}$ skrzydeł klasycznych o $60-70 \%$. Aby zabezpieczyć się przed przedwczesnym oderwaniem warstwy przyściennej od końcowej części skrzydeł w pobliżu krytycznego kąta natarcia, zastosowano zwichrzenie (skręcenie) geometryczne skrzydeł (twist) $\varepsilon$ (rys. 6).

Skręcenie geometryczne polega na obróceniu skrajnych cięciw profili skrzydła w dół w stosunku do profili nasadowych. Podczas opływu skrzydła uzyskuje się (poprzez skręcenie geometryczne) mniejsze kąty natarcia profili końcowych w stosunku do nasadowych, a tym samym wcześniej wspomniane korzystniejsze właściwości pilotażowe samolotu przy małych prędkościach. Zwichrzenie stosuje się wzdłuż całej rozpiętości lub tylko na jej części, np. w strefie lotek, w celu 


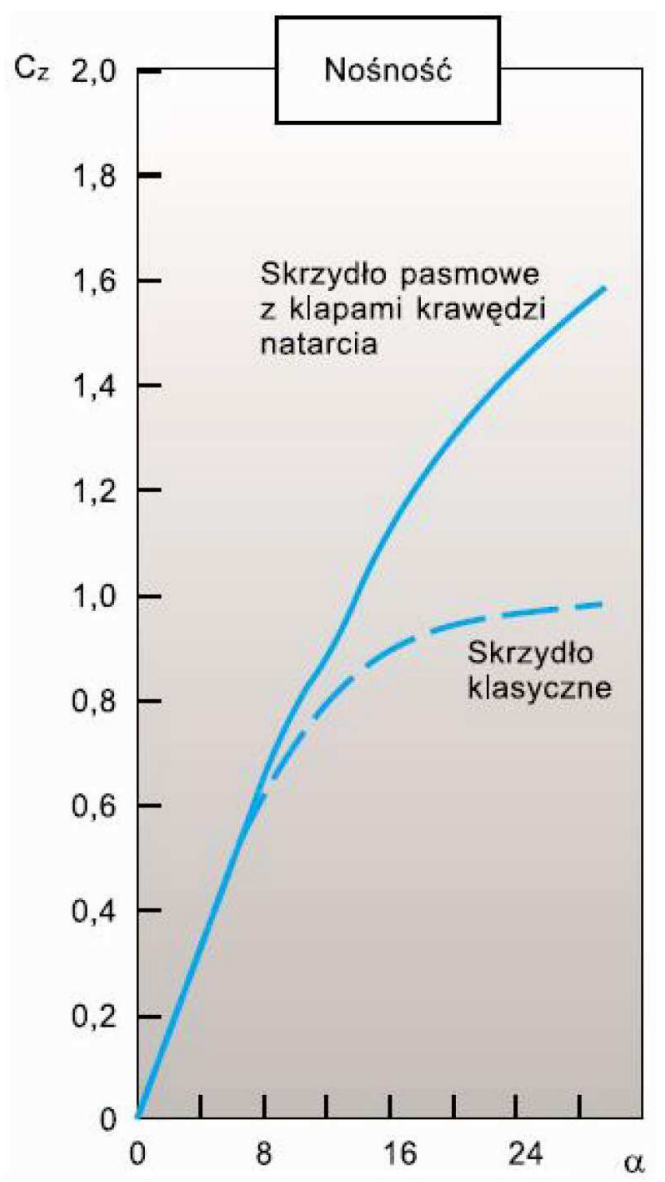

Rys. 5. Zależność współczynnika siły nośnej od kąta natarcia dla skrzydeł pasmowych z klapami krawędzi natarcia i dla skrzydeł klasycznych

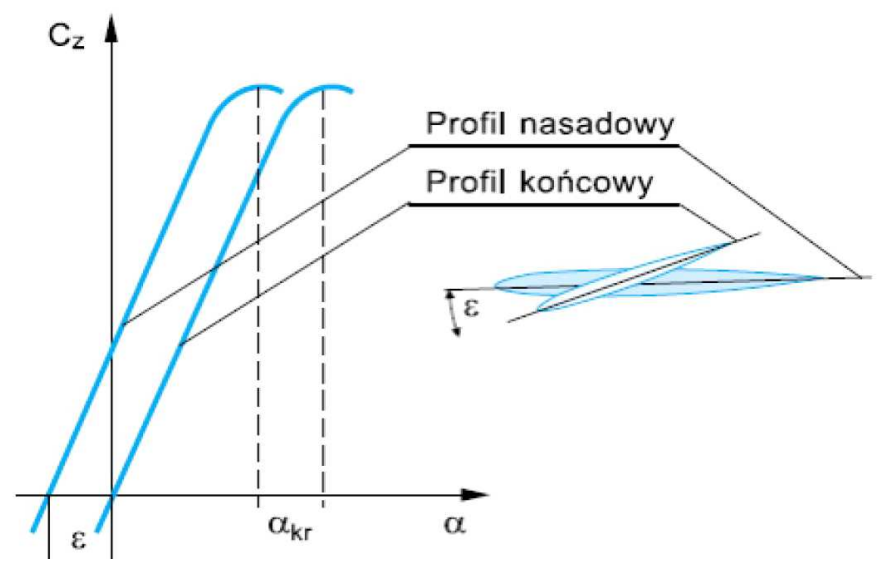

Rys. 6. Przebieg $c_{z}=f(\alpha)$ dla skrzydła skręconego geometrycznie

poprawienia ich pracy i zapewnienia skuteczności na dużych kątach natarcia. Dzięki skręceniu płata następuje zmniejszenie siły nośnej na skrzydle, a szczególnie na jego końcu. Rozkład siły nośnej wzdłuż rozpiętości jest korzystniejszy i powoduje zmniejszenie oporu indukowanego skrzydła. Ponadto skręcenie skrzydła poprawia poprzeczną stateczność i sterowność samolotu na dużych kątach natarcia, ponieważ profile końcowe pracują jeszcze na podkrytycznych kątach natarcia, kiedy profile przykadłubowe osiągnęły już krytyczny kąt natarcia. 


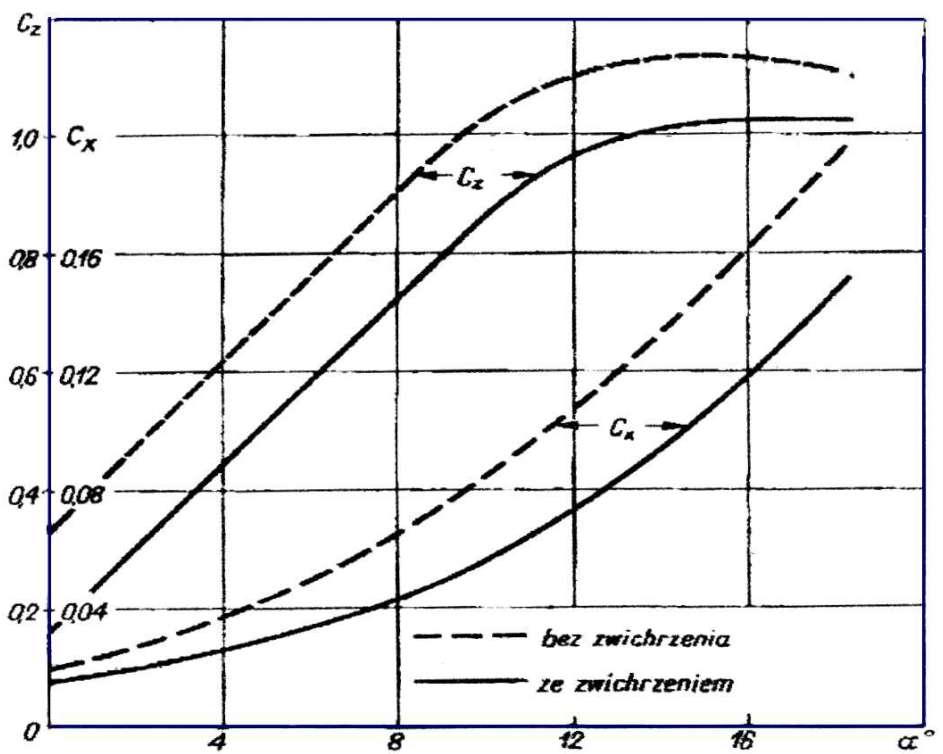

Rys. 7. Wpływ geometrycznego zwichrzenia skrzydła na współczynnik siły nośnej i współczynnik oporu [1], [2], [4]

Segment zewnętrzny ma obrys trapezowy przy stałych skosach krawędzi natarcia i spływu, bez uskoku. Skos krawędzi natarcia $\chi=40^{\circ}$; wydłużenie skrzydła $\lambda=3^{\circ}$; względna grubość profilu $g=4 \%$; zbieżność skrzydeł (taper ratio) $\eta=0,2275$; kąt wzniosu (dihedral) $\xi=0^{\circ}$; kąt zaklinowania (incidence) $\tau=0^{\circ}$; skręcenie geometryczne (twist) $\varepsilon=3^{\circ}$. Napływy o kącie skosu $75^{\circ}$ mają powierzchnię $S_{n}=4 \mathrm{~m}^{2}$. Na części zewnętrznej zastosowano profil laminarny NACA 64A-204 (National Advisory Committee for Aeronautic). Niedogodnością tak dobrego zaprojektowania płata od strony aerodynamicznej jest uzyskanie struktury skrzydła na tyle cienkiej, że aż uniemożliwiającej umieszczenie w skrzydle zespołów podwozia głównego, dlatego musiało ono zostać usytuowane w kadłubie. Głównac cechą profili laminarnych jest to, że ich maksymalna grubość położona jest w odległości od krawędzi natarcia od 35\% do $70 \%$ cięciwy profilu.

Wartość oporu całego samolotu, który posiada skrzydło laminarne, w zakresie małych kątów natarcia może być o 30\%-45\% mniejsza (na wykresie biegunowej $c_{z}=f\left(c_{x}\right)$ występuje charakterystyczny uskok) w stosunku do profilu klasycznego lub laminarnego, który zatracił swoje właściwości w wyniku niewłaściwego wykonania pokrycia (rys. 8). Inną ważną cechą profili laminarnych jest to, że gradient ciśnienia powietrza jest mały i tym mniejszy im dalej maksymalna grubość jest położona od krawędzi natarcia. Lokalne prędkości przepływu powietrza wokół profilu laminarnego mają małe wartości. Wadą jest to, iż profile laminarne czułe są na wszelkie uszkodzenia gładkości pokrycia i nawet wystający nit automatycznie zaburza warstwę przyścienną, powodując przejście w turbulentną.

Skrzydła wyposażone są w klapolotki (flaperons) o powierzchni stanowiącej prawie $10 \%$ powierzchni skrzydeł, spełniające zarówno funkcję klap krawędzi spływu (TEF - trailing edge flaps) jak i lotek, oraz w klapy krawędzi natarcia, których powierzchnia wynosi około $12 \%$ powierzchni płata.

Skrzydło F-16 ma zmienną grubość względną wzdłuż rozpiętości (grubością względną profilu nazywa się stosunek maksymalnej grubości profilu do jego cięciwy, wyrażony w procentach). Poza tym struktura nośna wewnętrznej części skrzydła (napływu) stanowi technologicznie jedną całość z kadłubem, natomiast skrzydła zewnętrznego (zasadniczego) została zbudowana w oparciu o jedenaście dźwigarów przenoszących obciążenia oraz pięć żeber zapewniających sztywność (trzy wzmocnione, do których mocuje się węzły na podwieszenia zewnętrzne), rys. 9. Kształt 


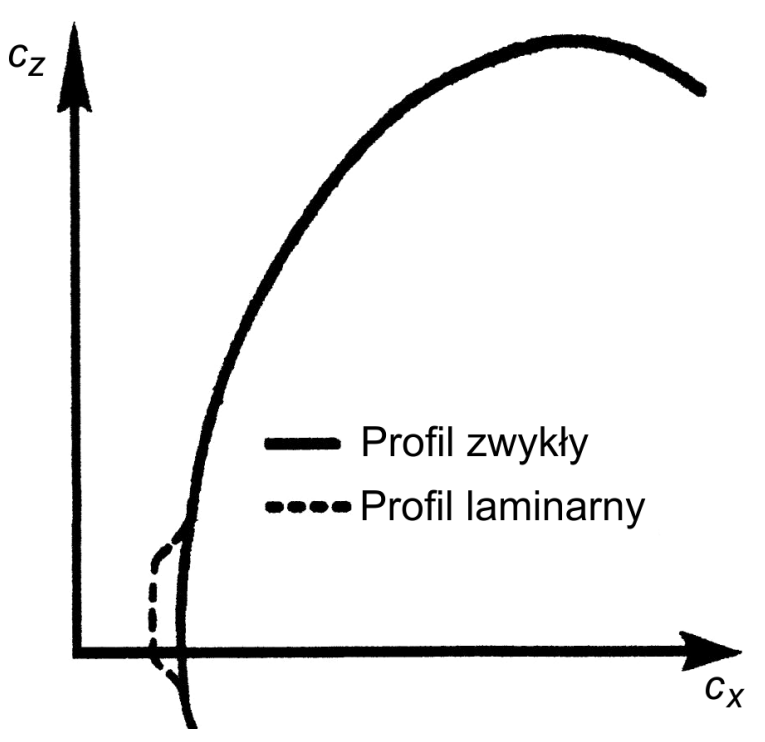

Rys. 8. Kształt biegunowej profilu klasycznego i laminarnego

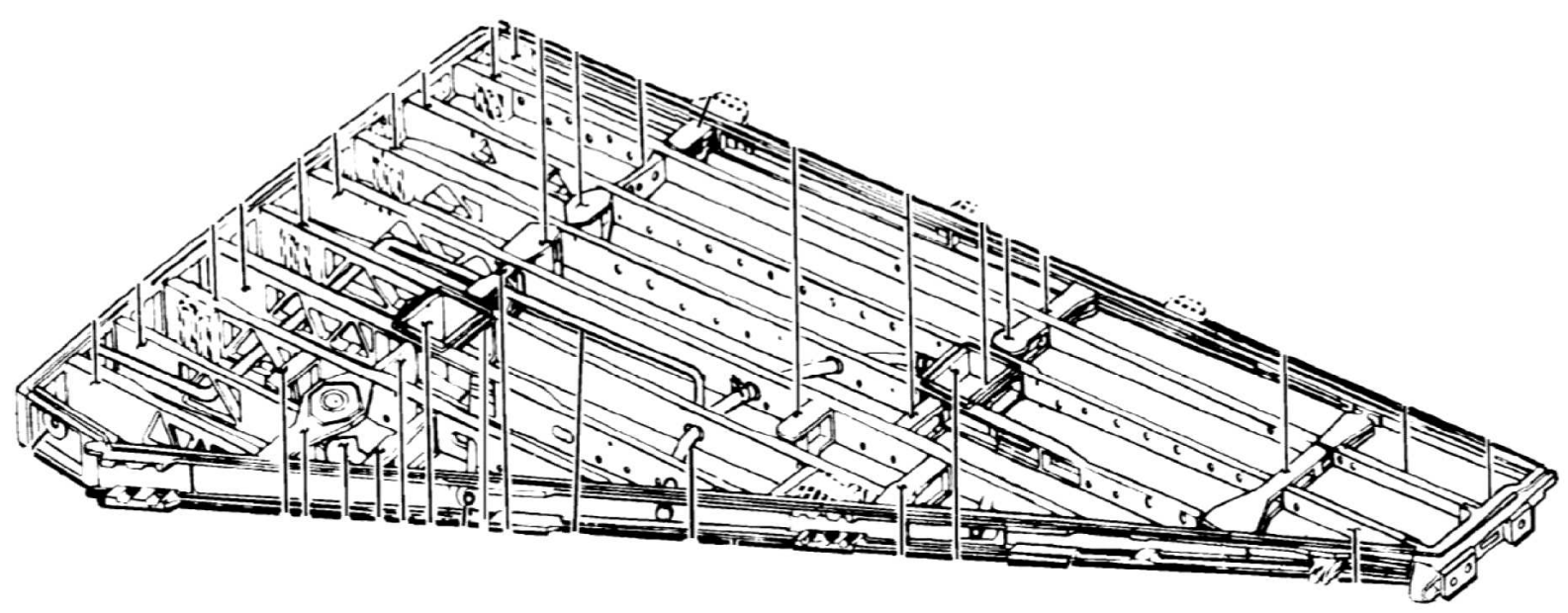

Rys. 9. Keson skrzydła zewnętrznego samolotu F-16

skrzydła nadawany jest przez pokrycie, które stanowi jedną niedzieloną część. Pokrycie przymocowane jest do dźwigarów, a połączenia mocujące wykonano w postaci nitowania płaskiego (bez wystających łbów nitów). W ten sposób wszystkie elementy struktury mają możliwość częściowego przejmowania obciążeń oddziaływujących w locie, a szczególnie w czasie wykonywania manewrów. Na końcówce skrzydła umieszczono wyrzutnię pocisków rakietowych, pełniącą jednocześbie rolę masy antyflatterowej.

\section{Podsumowanie}

F-16 charakteryzuje się cechami typowymi dla samolotu myśliwskiego. Wyróżnia się dużą manewrowością, posiadając przy tym zapas stateczności gwarantujący bezpieczeństwo.

Za stabilność lotu odpowiada komputer, gdyż nie są one statyczne podłużnie. Cechy te w połączeniu z dużym zasięgiem i udźwigiem spowodowały, że F-16 jest obecnie najliczniej stosowanym samolotem wielozadaniowym na świecie. 


\section{Bibliografia}

1. Matuszkiewicz J., Aerodynamika i mechanika lotu. Część I - Aerodynamika, WAT, Warszawa, 1981

2. Milkiewicz A., Rozwiązania aerodynamiczne samolotów myśliwskich - wspólczesnych oraz przetomu XX i XXI wieku, Przegląd WL i WOPK, 1988

3. Praca zbiorowa, NASA Technical Paper 1538: Simulator study of stall/post stall characteristics of a fighter airplane relaxed longitudial static stability, NASA, 1979

4. Szendzielorz C., Aerodynamika i mechanika lotu. Część II - Mechanika lotu, WAT, Warszawa, 1984

5. Wasilewski A., Samolot myśliwski F-16C/D Block 52 Advanced, Bellona, Warszawa, 2004

\section{Characteristics and technological solutions of the wing of F-16 Block 52+ aircraft}

The purpose of this article is to identify the existing model of the flight dynamics of F-16 aircraft available in the literature. This identification means a full understanding of the model, the simplifications used in it, the limitations imposed on the model and the determination of aerodynamic characteristics of the aircraft. Presentation of technological solutions aims at obtaining maximum maneuverability with low weight and low unit cost of production of this aircraft at the same time. 